\title{
Detection of virulence and specific genes of Salmonella sp. indigenous from Jember, Indonesia
}

\author{
RIA YULIAN ${ }^{1,2}$, ERLIA NARULITA ${ }^{1,2, \boldsymbol{v}}$, MOCHAMMAD IQBAL ${ }^{1}$, DESY ROCHMIYAH SARI ${ }^{1,2}$, \\ IRMA SURYANINGSIH ${ }^{1,2}$, DIAN EKA APRILIA FITRIA NINGRUM ${ }^{3}$ \\ ${ }^{1}$ Program of Biology Education, Faculty of Teacher Training and Education, Universitas Jember. Jl. Kalimantan X, Jember 68121, East Java, Indonesia. \\ Tel.: +62-331-330738, `email: erlia.fkip@unej.ac.id \\ ${ }^{2}$ Center for Development of Advanced Sciences and Technology, Universitas Jember. Jl. Kalimantan X, Jember 68121, East Java, Indonesia \\ ${ }^{3}$ Department of Islamic Primary School Teacher Education, Faculty of Tarbiyah and Teacher Training, Universitas Islam Negeri Maulana Malik Ibrahim \\ Malang. J1. Tarbiyah, Malang 65144, East Java, Indonesia
}

Manuscript received: 13 March 2020. Revision accepted: 3 June 2020.

\begin{abstract}
Yulian R, Narulita E, Iqbal M, Rochmiyah D, Suryaningsih I, Ningrum DEAF. 2020. Detection of virulence and specific genes of Salmonella sp. indigenous from Jember, Indonesia. Biodiversitas 21: 2889-2892. The bacterium Salmonella sp. is the most common cause of foodborne infection in humans. It has the ability to invAde the host, Salmonellosis is highly influenced by the combination of chromosome and plasmid in which Salmonella Pathogenesis Islands (SPIs) are the biggest gene in the chromosome that are responsible to build specific interaction between Salmonella and the host. This research performed detection on virulence and specific genes in the SPIs area using PCR method for two Salmonella spp. bacterial isolates originated from Jember which were KP2 and P21D. Seven pairs

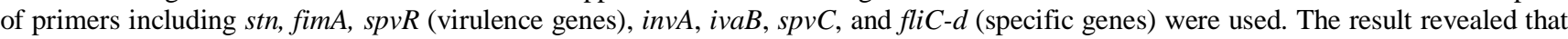
P21D bacteria containing 3 virulence genes i.e. $\operatorname{stn}$, fim $A$, and $s p v R$. Meanwhile, only two virulent genes $\operatorname{stn}$, and $\operatorname{spvR}$ were present in KP2 bacteria. For the detection of specific genes, three genes $i n v A$, $i v a B$, and $s p v C$ were present while fliC-d genes were not detected. Only two, invA, and $i v a B$ genes were detected in P21D bacteria, while $s p v C$, and $f l i C$ - $d$ were not detected.
\end{abstract}

Keywords: Salmonella, SPIs, virulence gene, specific gene

\section{INTRODUCTION}

All genes in the Salmonella chromosome are in the area that is called Salmonella Pathogenesis Island (SPIs) (Chaudhary et al. 2015; Andesfha, et al. 2019). SPIs in the Salmonella chromosome is responsible for building interaction between the Salmonella and the host (Sabbagh et al. 2010). The genes in the SPIs area can be treated as molecular marks to identify Salmonella and also the virulence type of those bacteria (Kumar et al. 2006). Specific genes that could be used to identify Salmonella bacteria had been widely reported. One of them was the detection of S.typhi using PCR with primer pairs such as invA, ivaB, fliC-d, spv genes (Kumar et al. 2006). viaB, prt, and $f l i C-d$ genes, each of them, was used to encode in synthesizing $\mathrm{Vi}$ (Capsule), $\mathrm{O}$ (LPS), and $\mathrm{H}$ antigen (flagellar) (Shanmugasamy et al. 2011). The virulence genes, i.e. $\operatorname{stn}$, fimA, and $\operatorname{sp} v R$ had been widely reported on many research especially for detection virulence genes in bacteria caused of foodborne disease (Naravaneni and Jamil 2005), for classification of Salmonella (Alphons and Jaap, 2005; Card et al. 2016), as well as for knowing nontyphoidal Salmonella in gastroenteritis (Araque 2009; Aoki et al. 2017).

The amplification of invA genes has been internationally acknowledged for the detection of Salmonella genus. invA gene is the primary gene in the operon invABC which encodes the protein in the inner membrane of Salmonella that is responsible for invAding intestinal epithelial cells of the host (Phumkhachorn and Rattanachaikunsopon 2017). flic-D gene-encoded flagellin protein genes in phase 1 (Shanmugasamy et al. 2011). Genes $i v a B$ and $f l i C-d$ encodes the synthesis of $\mathrm{Vi}$ (capsule), O (LPS), and antigen $\mathrm{H}$ (flagellar). Each antigen becomes the basis of detection and classification for Salmonella by Kauffmann-White scheme (Kumar et al. 2006; Mthembu 2019; Figueira and David 2012). spv gene holds the role in systemic infection by infecting host in the macrophage. $s p v$ gene allows to increase the virulence of $S$. enteritidis in the internal organs because one main function of $s p v$ operon is to potentiate the systemic spread of pathogen (Chaudhary et al. 2015). This research used $s p v C$ which was virulence-related gene in plasmid that is needed to survive in the host cell (Tekale et al. 2015).

Regarding the existence of virulence and specific genes of Salmonella, this research used two Jember Salmonella indigenous bacteria namely P21D and KP2 which were isolated from Puger and Kencong. There were 255 cases of food poisoning recorded in 2016 in Kencong and Puger (Diah 2016). Even though the status was decreasing, the bacterial contamination in Kencong area and surrounding was still detected in the early of March 2017 from the sampling conducted by Jember Health Department in which, in the sampling process, Salmonella $s p$. bacteria were still found. The recent case of food poisoning in Jember was in early of January 2020 (Health Crisis Center). Thus, this study aimed to detect virulence and specific gene contained in Jember Salmonella indigenous bacteria. 


\section{MATERIALS AND METHODS}

\section{Procedures}

Salmonella $s p$. culture

Two Salmonella isolates (KP2, and P21D) were obtained from fish and vegetable wastes from Puger and Kencong, respectively. Reactivation was done by inoculating the bacteria from SSA medium to LuriaBertani medium (LB). The bacteria were cultured for 24 hours in a shaker.

Isolation and extraction DNA of Salmonella $s p$.

The bacteria were grown in LB medium for 24 hours which then $1000 \mu$ laliquot was retrieved and centrifuged at $4^{\circ} \mathrm{C}, 1000 \mathrm{rpm}$ for 10 minutes. The obtained supernatant contained DNA transferred to other Eppendorf tubes and stored at $4^{\circ} \mathrm{C}$. DNA extraction by boiling was done with a modification. The collected material was placed into a tube containing $40 \mu \mathrm{L}$, then boiling for 10 minutes. The mixture was centrifuged at $12000 \mathrm{rpm}$ for 10 minutes. The supernatant was collected and $70 \mu \mathrm{L}$ volumes of cold absolute ethanol were added, then centrifuged for 20 minutes. The pellet was washed in $\mathrm{EtOH}$, dried the genome, and resuspended in TE buffer (Dashti et al. 2009).

\section{DNA amplification}

The first PCR amplification process was conducted using gradient temperature to obtain optimum temperature for each primer pairs (Table 1). The gradient temperature setting was based on melting temperature $\left(\mathrm{T}_{\mathrm{m}}\right)$ of each primer at $5^{\circ} \mathrm{C}$ below of $\mathrm{T}_{\mathrm{m}}$ with 35 cycles. The PCR condition was denaturated at $95^{\circ} \mathrm{C}$ for 2 minutes, followed by 35 cycles, denaturation at $95^{\circ} \mathrm{C}$ for 30 seconds, annealing temperature at $46.9^{\circ}-50.8^{\circ} \mathrm{C}$ for 30 seconds, and extension at $72^{\circ} \mathrm{C}$ for 45 seconds, and final extension at $72^{\circ} \mathrm{C}$ for 7 minutes (Sunar et al. 2014). The amplification products were separated by electrophoresis in $1 \%$ agarose gel stained with $5 \mu \mathrm{g}-/ \mathrm{ml}$ ethidium bromide using $1 \mathrm{~kb}$ DNA ladders as molecular-weight size marker.

\section{RESULTS AND DISCUSSION}

The research step initiated by conducting genomic DNA extraction using colony and boiling PCR method which was then checked using electrophoresis in $1 \%$ agarose gel. The genomic visualization results of two isolates were seen for $>1 \mathrm{kbp}$ band (Figure 1). Next, in PCR process, the amplification result of both Salmonella sp. samples which were KP2 and P21D showed difference in annealing temperature for each primer. The stn gene was amplified at annealing temperature of $46.9^{\circ} \mathrm{C}$. Meanwhile, both $s p v R$ gene, and fimA gene were amplified at the annealing temperature of $50,8^{\circ} \mathrm{C}$. For specific genes, the optimum annealing temperatures were inv $A$ gene $\left(50,8^{\circ} \mathrm{C}\right)$, $i v a B$ gene $\left(47^{\circ} \mathrm{C}\right), s p v C$ gene $\left(57^{\circ} \mathrm{C}\right)$, while fliC- $d$ gene did not show any amplified band at the optimum temperature gradient between $47^{\circ} \mathrm{C}-54^{\circ} \mathrm{C}$. The amplification result of stn gene showed there were 260 bp DNA bands on both samples (Figure 2). Salmonella enterotoxin (stn) is a gene encoding stn protein that causes gastroenteritis leading to nausea, vomiting, abdominal cramps, fever, and diarrhea. stn gene is detected in all Salmonella strains from broilers (Fekry et al. 2018). The virulence genes detected in this study were the $s t n$ gene, the fimA gene, and the $s p v R$ gene. The three genes in the Salmonella sp. are pathogenic. Virulence genes encode products that assist organisms in expressing virulence in host cells (Muthu et al. 2014). According to Thomas and Wigneshweraraj (2014) products of genes that facilitate successful colonization and bacterial survival or cause damage to the host are considered as determinants of virulence. The presence of virulence genes in Salmonella is related to the causes of salmonellosis and foodborne diseases in humans. Salmonella virulence is a combination of chromosome and plasmid factors (Chaudhary et al. 2015).

Table 1. Primers for detection of virulence and specific genes of Salmonella sp.

\begin{tabular}{|c|c|c|c|}
\hline $\begin{array}{c}\text { Gene } \\
\text { target }\end{array}$ & Primer sequence (5-3') & $\begin{array}{l}\text { Target size } \\
\text { (bp) }\end{array}$ & Reference \\
\hline \multirow[t]{2}{*}{ fimA } & F: CCT TTC TCC ATC GTC CTG AA & 85 & Chaudhary et al. (2015) \\
\hline & R: TGG TGT TAT CTG CCT GAC CA & & \\
\hline \multirow[t]{2}{*}{ Stn } & F: CTT TGG TCG TAA AAT AAG GCG & 260 & Chaudhary et al. (2015) \\
\hline & R: TGC CCA AAG CAG AGA GAT TC & & \\
\hline \multirow[t]{2}{*}{$\operatorname{spv} R$} & F: CAG GTT CCT TCA GTA TCG CA & 310 & Chaudhary et al. (2015) \\
\hline & R: TTT GGC CGG AAA TGG TCA GT & & \\
\hline \multirow[t]{2}{*}{ invA } & F: GTG AAA TTA TCG CCA CGT TCG GGC AA & 284 & Chaudhary et al. (2015) \\
\hline & R: TCA TCG CAC CGT CAA AGG AAC C & & \\
\hline \multirow[t]{2}{*}{$i v a B$} & F: GTT ATT TCA GCA TAA GGA G & 599 & Phumkhachorn and Rattanachaikunsopon (2017) \\
\hline & R: ACT TGT CCG TGT TTT ACT C & & \\
\hline \multirow[t]{2}{*}{$f l i C-d$} & F: ACT CAG GCT TCC CGT AAC GC & 763 & Phumkhachorn and Rattanachaikunsopon (2017) \\
\hline & R: GGC TAG TAT TGT CCT TAT CG G & & \\
\hline \multirow[t]{2}{*}{$\operatorname{spvC}$} & F: ACT CCT TGC ACA ACC AAA TGC GGA & 571 & Chaudhary et al. (2015) \\
\hline & R: TGT CTT CTG CAT TTC GCC ACC ATC A & & \\
\hline
\end{tabular}




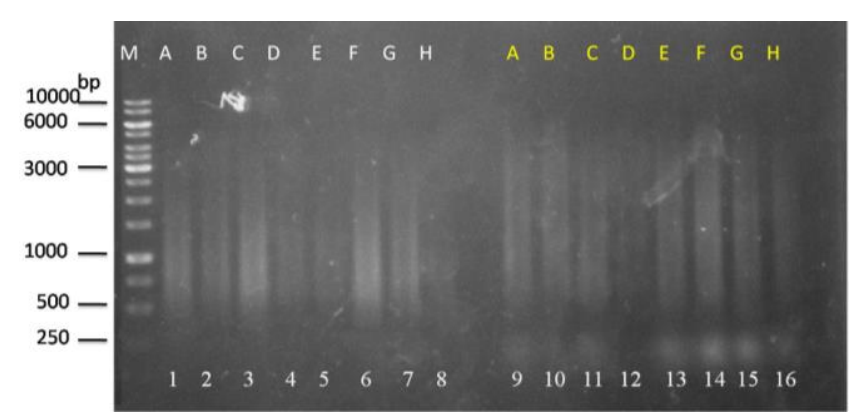

Figure 1. Electroforegram of flicd amplification showed no band at all. M: marker; line 1-8: Salmonella sp. P21D; and line 9-16: Salmonella sp. KP2

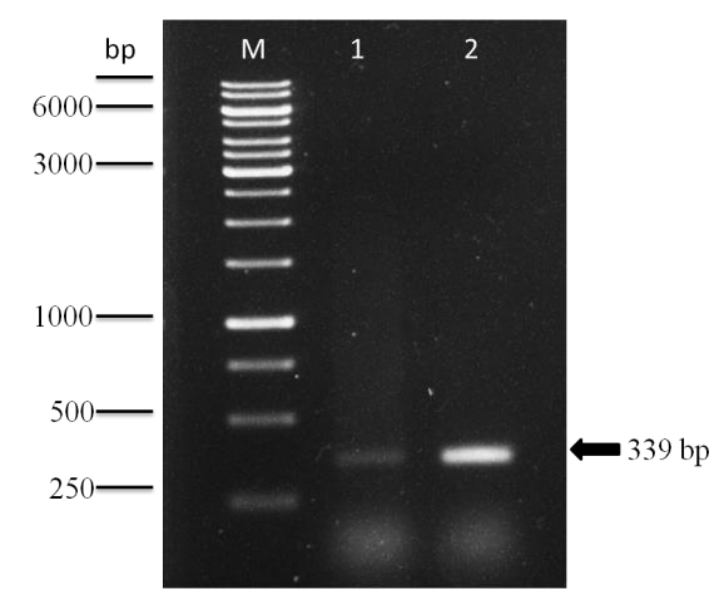

Figure 2. $\operatorname{stn}$ gene with size of 339 bp. Line M: marker; line 1: Salmonella sp. P21D; and line 2: Salmonella sp. KP2

Salmonella sp. is a member of Enterobacteriaceae, Gram-negative, rod-shaped, non-spherical bacteria, and generally moves using peritrich flagellum (Araque 2009). Salmonella bacteria have facultative anaerobic properties to grow at a temperature range of $5-45^{\circ} \mathrm{C}$ with the optimum at $35-37^{\circ} \mathrm{C}$. Other characteristics of Salmonella are that they multiply by dividing, easy to grow on simple mediums, and resistant to certain chemicals like. The DNA band of fimA gene only appeared on P21D while KP2 produced no bands (Figure 3).

The appearance of DNA band on the P21D indicated the presence of fimA gene while bacteria KP2 have no fimA gene. fimA is a fimbriae encoding gene in Salmonella (Zeiner et al. 2019). Fimbriae are found a lot on the enteric bacteria surface and mediating the attachment to eukaryotic cells. Type-1 fimbriae protein of Salmonella typhi was encoded by fimA gene group, with fimA assigned as single transcription unit. Based on amplification result of sample $\mathrm{KP} 2$, these bacteria have no type 1 fimbriae protein which contain fimA gene. Sample KP2 might have another fimbriae gene from fimbrial gene cluster. FimA is a fimbria coding gene in Salmonella. Fimbria is found in many

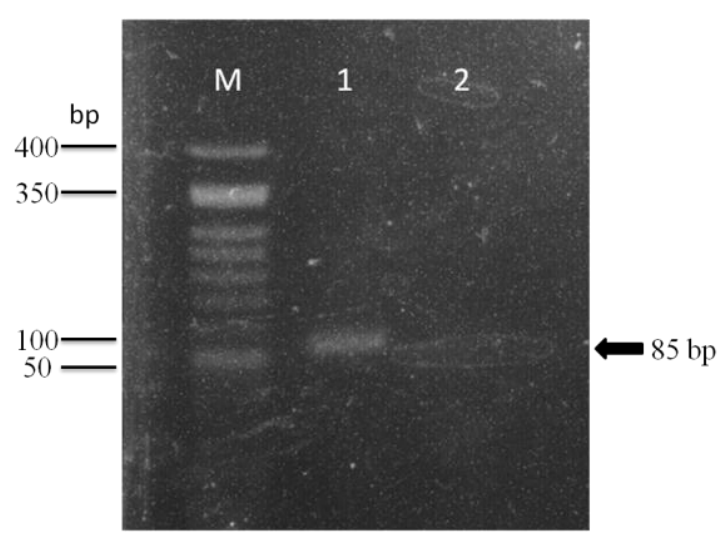

Figure 3. fimA gene with size of $85 \mathrm{bp}$. Line M: marker; line 1: Salmonella sp. P21D; and line 2: Salmonella sp. KP2

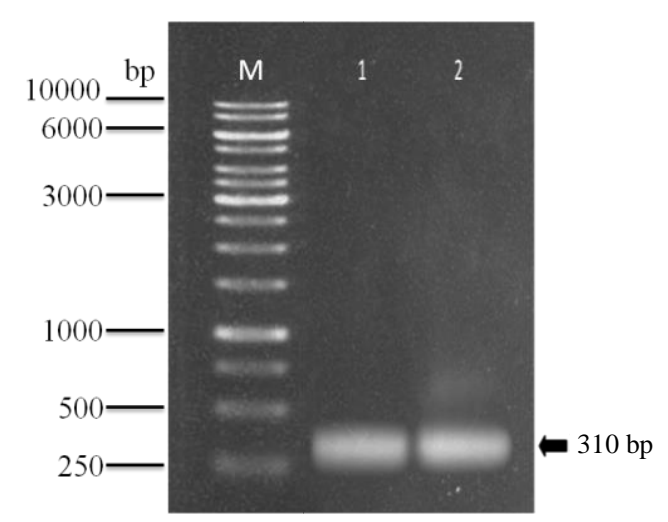

Figure 4. $s p v R$ gene with size of $310 \mathrm{bp}$. Line M: marker; line 1: Salmonella sp. P21D; and line 2: Salmonella sp. KP2

surfaces of enteric bacteria and functions for attachment to eukaryotic cells.

Bacteria can be classified based on phylogeny (to see the relationship between Salmonella bacteria). A phylogenetic tree can be made by looking at the genome sequence of the bacteria using $16 \mathrm{~S}$ rRNA analysis. Around 2,463 Salmonella serotypes were placed under 2 species due to differences in the genome sequence of the $16 \mathrm{~S}$ rRNA analysis results, including Salmonella enterica (2443 serotypes) and Salmonella bongori (20 serotypes).

spvR gene could be amplified on the two samples (Figure 4). The size of amplified DNA was $310 \mathrm{bp}$. The appearance of single band on the amplification result revealed that both samples possessed gen $s p v R$ with thick band displaying a high DNA concentration. $s p v$ gene (Salmonella plasmid virulence) is a $7.8 \mathrm{~kb}$ locus consisting of 5 genes, $s p v R$, located in a plasmid which is generally associated with some serotypes. $s p v$ gene possesses the ability to increase the severity of enteritis, infection, and persistence at extra-intestinal sites (Oliveira et al. 2003; Alphons and Jaap 2005; Card et al. 2016). The spv gene has the ability to increase the severity of enteritis and 
infection and persistence at the extraintestinal location (Oliviera et al. 2003).

invA gene was amplified on the two Salmonella samples revealed a 244 bp band (Figure 5A). On the P21D bacteria sample, the band was slightly thinner than the band on KP2. The thickness of the bands may be due to the concentration of DNA in the bacteria. invA gene is the specific primer that owns solely by genus Salmonella which means that the two bacterial samples used in this research belong to Salmonella genus (Phumkhachorn and Rattanachaikunsopon 2017). invA gene makes the epithelial cell invAsion process, so when salmonellosis occurs, this gene will appear. Forty isolates of Salmonella had been studied for detection of invA gene using PCR, and invA appeared in all of the isolates (Sharma and Das 2016). The amplification result of $i v a B$ primer gene on the two samples could be seen from the 599 bp band (Phumkhachorn and Rattanachaikunsopon 2017). Sample P21D has a thinner band than sample KP2 (Figure 5B). $i v a B$ gene is especially owned by Salmonella typhi dan Salmonella paratyphi. The function of this gene is to operate in $v i a B$ area where locus on chromosome contains specific structural genes to express antigen Vi (Virulence) (Xiong et al. 2017).

From the result of the amplification, $s p v C$ primer gene only appeared in sample 2 (KP2) at 571 bp (Figure 6), while sample 1 (P21D) did not contain spvC gene. Gene spv (Salmonella plasmid virulence) is a $7.8 \mathrm{~kb}$ locus consisting of 5 genes namely $\operatorname{sp} v A B$ (Alphons and Jaap 2005; Card et al. 2016). P21D bacteria did not contain $s p v C$ gene, so they do not possess the ability in partial virulence. However, it is possible for P21D sample to have the other 5 $s p v$ genes. According to the research, $s p v$ primer gene, $s p v R$, and $p s v C$, on 102 Salmonella enteritidis samples from poultry, human feces and foodborne disease plague were successfully amplified (Oliveira et al. 2003). The outcome was detection of $91.2 \% s p v R$ and $90.2 \% s p v C$ virulence genes from all Salmonella enteritidis samples. $s p v R$ gene has a role to regulate LysR protein to express other spv genes (Alphons and Jaap 2005; Card et al. 2016). The absence of $s p v R$ gene might result in avirulence while the absence of $s p v C$ gene could show partial virulence. Salmonella Enterica Serovar Typhimurium strain, found on the rat, was inoculated subcutaneously, and contained $s p v B$ gene (Matsui et al. 2001). spvB gene expressed ADPribosylation enzyme which inhibited the process of polymerization actin in host cell, so it could inhibit the fusion between phagocyte and lysosome (Chu et al. 2016). $s p v D$ gene reduced the pro-inflammation regulation by inhibiting promotor activation which was controlled by NF-kB (Silva et al. 2017; Liu et al. 2017). The $s p v R$ gene functions to regulate the LysR essential protein to express other spv genes. Without the spvR gene, it may be avirulent while the absence of the $s p v C$ gene can show partial virulence.

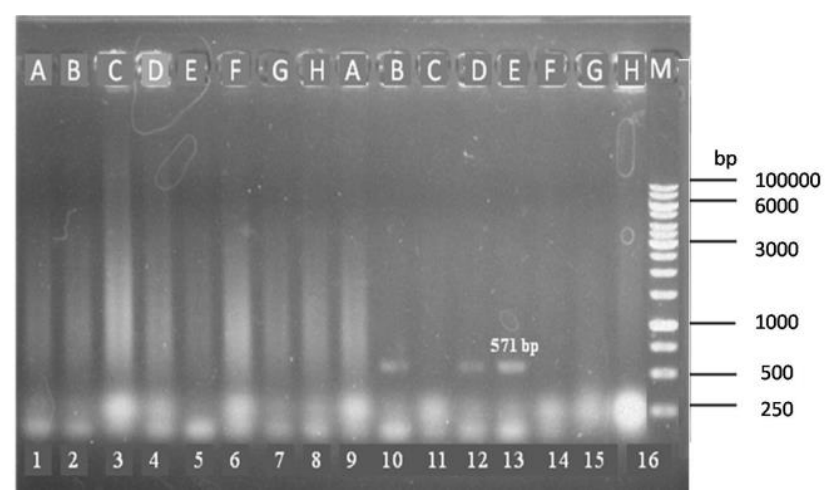

Figure 6. Electroforegram of $s p v C$ gene amplification of $571 \mathrm{bp}$. Line M: marker; line 1-8: Salmonella sp. P21D; and line 9-16: Salmonella sp. KP2

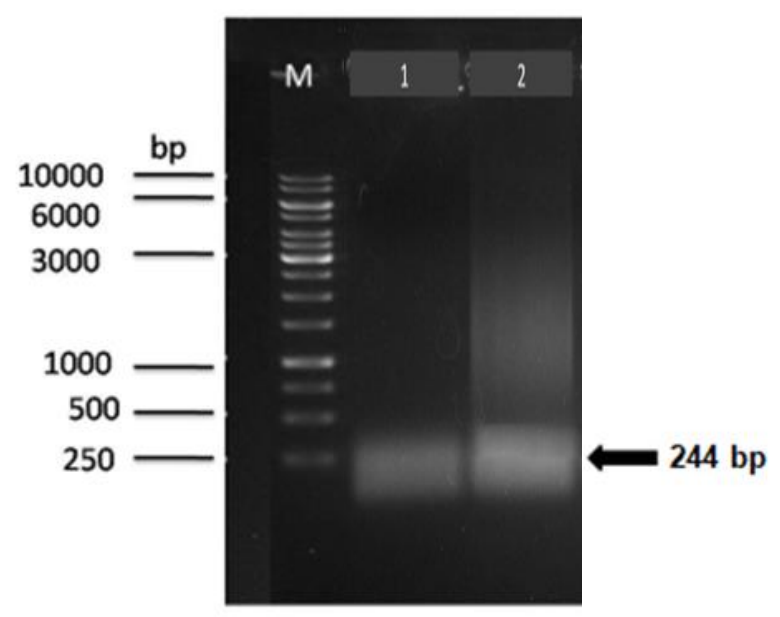

$\mathbf{A}$

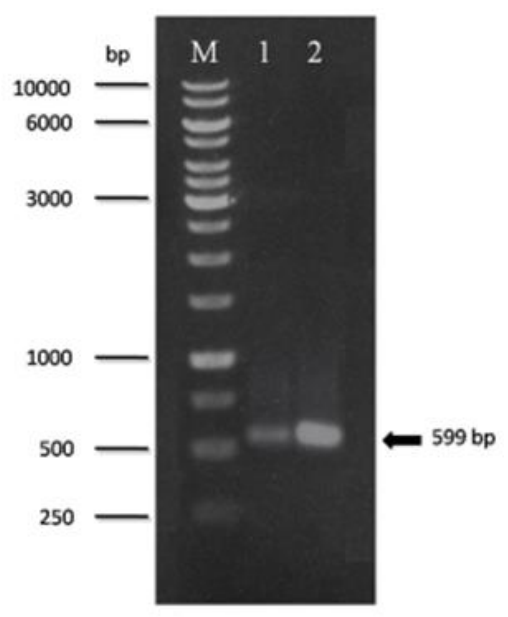

B

Figure 5. Electroforegram of invA (A) volume $25 \mu \mathrm{L}$ and ivaB (B) volume $3 \mu \mathrm{L}$ genes with size of 599 and 244 bp, respectively. Line M: marker; line 1: Salmonella sp. P21D; and line 2: Salmonella sp. KP2 
In summarize, the detection result of virulence and specific genes on two Salmonella sp. bacterial isolates from Jember showed the presence of virulence genes namely stn, fimA, and $s p v R$ in P21D isolate. Meanwhile, the specific genes were invA, dan $i v a B$. In the KP2 isolate, virulence genes were $s t n$, dan $s p v R$ while the detected specific genes were $i n v A$, ivaB, dan $s p v C$. Many virulence factors have been shown to play various roles in the pathogenesis of Salmonella infections. These factors include flagella, capsules, plasmids, adhesion systems, and type 3 secretion systems (T3SS) encoded on the pathogenic islands of Salmonella (SPI)-1 and SPI-2 and other SPI.

\section{ACKNOWLEDGEMENTS}

This work was supported by the Research and Community Service Institute (LP2M), University of Jember, Indonesia through Hibah Mendukung IDB contract number of 3235/UN25.3.1/LT/2019.

\section{REFERENCES}

Alphons JAMV, Jaap EVD. 2005. Distribution of "classic" virulence factors among Salmonella spp. FEMS. Immunol Med Microbiol 44: 251-259.

Andesfha E, Agustin I, Mayasari NLPI, Rahayuningtyas I, Istiyaningsih J. 2019. Detection of Salmonella pathogenicity island and Salmonella plasmid virulence genes in Salmonella enteritidis originated from layer and broiler farms in Java Island. J Adv Vet Anim Res 3 (6): 2311-7710.

Aoki Y, Katsuhiko K, Hinorobu K, Masayoshi S, Yukie A, Riu H, Yudai W, Akihito H. 2017. Clinical features of children with nontyphoidal Salmonella bacteremia: A single institution survey in rural Japan. PLoS One 12 (6): e0176990. DOI: 10.1371/journal.pone.0176990.

Araque M. 2009. Nontypoidal Salmonella Gastroenteritis in Pediatric Patients from urban Area in the city of Merida, Venezuela. J Infect Dev Control 3 (1): 28-34.

Card R, Kelly V, Mary B, John S, William C, Tony S, Rob D, Muna FA. 2016. Virulence Characterisation of Salmonella enterica Isolates of Differing Antimicrobial Resistance Recovered from UK Livestock and Imported Meat Samples. Front Microbiol 2: 1-11.

Chaudhary JH, Nayak JB, Brahmbhatt MN, Makwana PP. 2015 Virulence Genes Detection of Salmonella Serovars Isolated from Pork and Slaughterhouse Environment in Ahmedabad, Gujarat. Vet World 8 (1): 121-124.

Chu Y, Gao S, Wang T, Yan J, Xu G, Li Y, Niu H, Huang R, Wu S. 2016. A novel contribution of $s p v B$ to pathogenesis of Salmonella typhimurium by inhibiting autophagy in host cells. Oncotarget 7 (7): 8295-8309.

Dashti A, Jadaon MM, Abdulsamad AM, Dhasti. 2009. Heat Treatment of Bacteria: A Simple Method of DNA Extraction for Molecular Techniques. Kuwait Med J 41 (2): 117-122.

Fekry E, Abdeen E, Ammar AM, Hussien AE. 2018. Molecular Detection of InvA, OmpA and Stn Genes in Salmonella Serovars from Broilers in Egypt. Alex J Vet Sci 56 (1): 69-74.
Figueira R, David WH. 2012. Functions of the Salmonella Pathogenicity Island 2 (SPI-2) Type III Secretion System Effectors. Microbiol 128: 1147-1161.

Health Crisis Center. 2016. Kejadian Luar Biasa (KLB)-Keracunan di Jember, Jawa Timur. http://pusatkrisis.kemkes.go.id/kejadian-luarbiasa-klb---keracunan--di-jember-jawa-timur-04-09-2016 [Indonesian]

Health Crisis Center. 2020. Kejadian Luar Biasa (KLB)-Keracunan di Jember, Jawa Timur. http://www.pusatkrisis.kemkes.go.id/KejadianLuar-Biasa- (KLB)---Keracunan--di-JEMBER-JAWA-TIMUR-0201-2020-42. [Indonesian]

Kumar S, Balakrishna K, Batra H. 2006. Detection of Salmonella enterica serovar typhi (S. typhi) by selective amplification of invA, viaB, fliC-d and prt genes by Polymerase Chain Reaction in multiplex format. Lett Appl Microbiol 42 (2): 149-154.

Liu T, Lingyun Z, Donghyun J, Shao-Cong, S. 2017. NG-kB signaling in inflammation. Sig Transduct Target Ther 2: 17023.

Matsui H, Bacot CM, Garlington WA, Doyle TJ, Roberts S, Gulig PA. 2001. Virulence plasmid-borne $s p v B$ and $s p v C$ Genes can replace the 90 kilobase plasmid in conferring virulence to Salmonella enterica serovar typhimurium in subcutaneously inoculated mice. J Bacteriol 183 (15): 4652-8. DOI: 10.1128/JB.183.15.4652-4658.2001.

Mthembu TP, Oliver TZ, Mohamed EEZ. 2019. Detection and molecular identification of Salmonella virulence genes in livestock production systems in South Africa. Pathogens 1 (124): 1-17.

Muthu G, Suresh A, VishnuPrabu D, Munirajan AK, Mary SE, Sathishkumar E, Gopinath P, Srivani S. 2014. Detection of virulence genes from Salmonella species in Chennai, India. CIBTech J Microbiol 3 (1): 11-14.

Oliveira SD, Rodenbusch CR, Michae GB, Cardoso MI, Canal CW, Brandelli A. 2003. Detection of virulence genes in Salmonella enteritidis isolated from different sources. Braz J Microbiol 34 (1): 123-124.

Phumkhachorn P, Rattanachaikunsopon P. 2017. Detection of Viable Salmonella typhi using Three Primer Pairs Specific to invA, ivaB, and fliC-d Genes. Emir J Food Agr 29 (4): 312-316.

Sabbagh SC, Forest CG, Lapage C, Leclerc JM, Daigle F. 2010. Uncovering distinctive features in the genomes of Salmonella enterica serovars typhimurium and typhi. FEMS Microbial Lett 305 (1): 1-13.

Shanmugasamy M, Velayutham T, Rajeswar J. 2011. InvA gene-specific PCR for detection of Salmonella from broilers. Vet World 4 (12):562564.

Sharma I, Das K. 2016. Detection of invA gene in isolated Salmonella from marketed poultry meat by PCR assay. J Food Process Technol 2 (1):1-4.

Silva C, Puente JL, Calva E. 2017. Salmonella virulence plasmid pathogenesis and ecology. Pathog Dis 75: 6. DOI: 10.1093/femspd/ftx070.

Sunar NM, Stentiford, Stewart DI, Fletcher LA. 2014. Molecular techniques to characterize the invA Genes of Salmonella spp. for pathogen inactivation study in composting. Orbit 13 (1): 43-46.

Tekale AA, Savalia CV, Kshirsagar DP, Brahmbhatt MN, Chatur YA. 2015. Detection and virulence gene characterization of Salmonella isolates from fish by conventional and molecular methods. J Vet Pub Hlth 13 (1): 43-46.

Xiong K, Chunyue Z, Zhijin C, Chunping Z, Yong T, Xiancai R, Yanguang C. 2017. Vi capsular polysaccharide produced by recombinant Salmonella enterica serovar paratyphi a confers immunoprotection against infection by Salmonella enterica serovar typhi. Front Cell Infect Microbiol 7: 135. DOI: 10.3389/fcimb.2017.00135.

Zeiner SA, Dwyer BE, Clegg S. 2019. FimA, FimF, and FimH are necessary for assembly of type 1 fimbriae on serovar typhimurium. J Infect Immun 80 (9): 3289-3296. 